\section{1}

\title{
Minimum Information for Reusable Arthropod Abundance ㅁata (MIReAAD)
}

\section{Myriad: a countless or extremely great number}

Samuel Rund*, srund@nd.edu, VectorBase, Department of Biological Science, University of Notre Dame, IN, USA.

Kyle Braak, kyle.braak@gmail.com, Global Biodiversity Information Facility (GBIF) Secretariat, Copenhagen, Denmark

Lauren Cator, 1.cator@imperial.ac.uk, Department of Life Sciences, Imperial College London, UK

Kyle Copas, kcopas@gbif.org, Global Biodiversity Information Facility (GBIF) Secretariat, Copenhagen, Denmark

Scott J. Emrich, semrich@utk.edu, Department of Electrical Engineering and Computer Science, University of Tennessee, Knoxville, TN

Gloria I. Giraldo-Calderón, ggiraldo@nd.edu, VectorBase - Bioinformatics Resource for Invertebrate Vectors of Human Pathogens, Department of Biological Science, University of Notre Dame, IN, USA.

Michael A. Johansson, mjohansson@cdc.gov, Division of Vector-Borne Diseases, Centers for Disease Control and Prevention, 1324 Calle Cañada, San Juan, PR 00920; Department of Epidemiology, Harvard School of Public Health, 677 Huntington Ave, Boston, MA 02115

Naveed Heydari, naveedheydari@gmail.com, Center for Global Health and Translational Science, State University of New York Upstate Medical University, Syracuse, NY 544 S Vance St, Lakewood, CO, 80226, USA

Donald Hobern, dhobern@gbif.org, Global Biodiversity Information Facility (GBIF) Secretariat, Copenhagen, Denmark

Sarah A. Kelly, s.kelly@imperial.ac.uk, VectorBase, Vector Immunogenomics and Infection Laboratory, Department of Life Sciences, Imperial College London, UK

Daniel Lawson, daniel.lawson@imperial.ac.uk, VectorBase and Vector Immunogenomics and Infection Laboratory, Department of Life Sciences, Imperial College London, UK 
42 Cynthia Lord, clord@ufl.edu, Florida Medical Entomology Lab, University of Florida-IFAS,

43 Vero Beach, FL

Robert M MacCallum, r.maccallum@imperial.ac.uk, VectorBase and Vector Immunogenomics

Dominique G. Roche, dominique.roche@mail.mcgill.ca, Institute of Biology, University of Neuchâtel, 2000, Neuchâtel, Switzerland

Sadie J. Ryan, sjryan@ufl.edu, Quantitative Disease Ecology and Conservation Lab, Department of Geography, University of Florida, Gainesville, FL 32601 USA; Emerging Pathogens Institute, University of Florida, Gainesville, FL 32610 USA; College of Life Sciences, University of Kwa-

Zulu Natal, Durban, South Africa

Dmitry Schigel, dschigel@gbif.org, Global Biodiversity Information Facility (GBIF) Secretariat, 57 Copenhagen, Denmark

Kurt Vandegrift, kjv1@psu.edu, Center for Infectious Disease Dynamics, Department of

Matthew Watts, m.watts@imperial.ac.uk, Department of Life Sciences, Imperial College

Jennifer M. Zaspel, zaspelj@mpm.edu, Department of Zoology, Milwaukee Public Museum, 800

Samraat Pawar*, s.pawar@imperial.ac.uk, Department of Life Sciences, Imperial College

\section{Abstract}

73 Arthropods play a dominant role in natural and human-modified terrestrial ecosystem dynamics.

74 Spatially-explicit population time-series are crucial for statistical or mathematical models of

75 these dynamics and assessment of their veterinary, medical, agricultural, and ecological impacts.

76 Arthropod data have been collected world-wide for over a century, but remain scattered and

77 largely inaccessible. With the ever-present and growing threat of arthropod vectors of infectious 
78 diseases and pest species, there are enormous amounts of historical and ongoing surveillance.

79 These data are currently reported in a wide variety of formats, typically lacking sufficient

80 metadata to make reuse and re-analysis possible. We present the first minimum information

81 standard for arthropod abundance. Developed with broad stakeholder collaboration, it balances

82 sufficiency for reuse with the practicality of preparing the data for submission. It is designed to

83 optimize data (re-)usability from the "FAIR," (Findable, Accessible, Interoperable, and

84 Reusable) principles of public data archiving (PDA). This standard will facilitate data unification

85 across research initiatives and communities dedicated to surveillance for detection and control of

86 vector-borne diseases and pests.

\section{Introduction}

88 Arthropods play a dominant role in the dynamics of practically all natural and human-modified

89 terrestrial ecosystems ${ }^{1-3}$, and have significant economic and health effects. For example, certain

90 insects provide significant economic benefits (e.g. pollination) exceeding $\$ 57$ billion a year to

91 the United States alone ${ }^{4}$. Meanwhile, invasive insects cost an estimated $\$ 70$ billion dollars per

92 year globally ${ }^{5}$ and insect pests may reduce agricultural harvests by up to $16 \%$, with an equal

93 amount of further losses of harvested goods ${ }^{6}$. Particularly noteworthy is a subset of arthropods

94 that are disease vectors, transmitting pathogens to and between animals as well as plants. Vector-

95 borne diseases cause billions of dollars in crop and livestock losses, every year ${ }^{7-9}$. In humans,

96 vector borne diseases account for more than $17 \%$ of all infectious diseases (e.g. malaria, Chagas,

97 dengue, and leishmaniasis, Zika, West Nile, Lyme disease, and sleeping sickness), with hundreds

98 of thousands of deaths, hundreds of millions of cases, and billions of people at risk, annually ${ }^{10,11}$. 
100 The current economic and health burden of arthropod pests, exacerbated by invasive species, and

101 uncertain effects of climate change ${ }^{12,13}$, has driven significant research programs and data

102 collection efforts. These include crop pest, mosquito, and tick survey and reporting initiatives ${ }^{14-}$

$103{ }^{18}$, citizen science projects ${ }^{19-21}$, and digitization of museum specimen data ${ }^{22,23}$, all yielding a rich

104 and growing trove of field-based data spanning multiple spatial and temporal scales. Monitoring

105 arthropod abundance (e.g. Figure 1) in different disciplines (e.g., biodiversity research, pest-

106 control assessment, vector-borne disease monitoring, or pollination research) uses similar

107 techniques, with similar objectives: to quantify abundance, phenology and geographical ranges

108 of target arthropod species. Despite a growing number of data collections, they are often not

109 reusable, or comparable to similar data, due to a lack of standardization and metadata. In

110 contrast, the advent of the deposition of data from high-throughput technologies (e.g. NCBI and

111 GenBank), data and code sharing, and other practices to improve transparency and reusability of

112 research results are increasing rapidly across the sciences ${ }^{24-29}$. Furthering these advances through

113 standardization and public archiving of arthropod abundance data can bring significant benefits,

114 including (1) supporting empirical parameterization and validation of mathematical models (e.g.

115 of pest or disease emergence and spread), (2) validation of model predictions, (3) reduction in

116 the duplication of expensive empirical research, and (4) revealing new patterns and questions

117 through meta-analyses ${ }^{30-33}$. This will also lead to substantial public benefit through improved

118 human, animal, plant, and ecosystem health, and reduced economic costs.

120 A key impediment to the re-use of these data is the lack of adequate metadata or data descriptors

121 (i.e. data about the data) $)^{34-37}$. In general, for data to be most valuable to the scientific community, 
122 they should meet the FAIR Principles - they should be Findable, Accessible, Interoperable and

123 Reusable - and delineate the key components of good data management and stewardship

124 practices $^{38,39}$. Data are Findable and Accessible when they are archived and freely downloadable

125 from an online public data repository that is indexed and easily searchable. Interoperability and

126 reusability describe the ease with which humans or computer programs can understand the data

127 (e.g. via metadata) and explore/re-use them across a variety of non-proprietary platforms. Even

128 when data are available, metadata for arthropod abundance data are often absent or not readily

129 interpretable, limiting their reusability at a fundamental level.

\section{Results}

\section{A minimum information standard for arthropod abundance data}

132 Here, we present a Minimum Information for Reusable Arthropod Abundance Data (MIReAAD)

133 standard for reporting primarily longitudinal (repeated, temporally explicit) field-based

134 collections of arthropods. In the same manner as has been developed in other biological

135 disciplines ${ }^{40-45}$, this standard is "minimum" because it defines the necessary minimal information

136 required to understand and reuse a dataset without consulting any further text, materials, or

137 methods $^{46}$. MIReAAD is designed to facilitate data archiving efforts of publishers and field

138 researchers. It is not a data model and therefore does not define controlled vocabularies, or

139 specific field titles, but should be easy to understand, and interpret by the wider scientific

140 community $^{46}$.

142 The minimal standards are separated into two components, metadata and data. For each

143 component, we provide a description of the information that should be included, 
144 recommendations for how to make that information as useful as possible, and examples. The

145 metadata component (Table 1) includes information for the origin of the data set (e.g. study

146 information and licensing for usage). The second component (Table 2) lists and describes

147 specific data fields that should be included in data collection sheets. We also provide

148 recommendations and examples to demonstrate how these recommendations can be

149 implemented. MIReAAD was designed to match the data that are generally collected by

150 academic researchers and surveillance initiatives, and can serve as a checklist for important

151 information that needs to be recorded but is often unintentionally omitted (e.g. Figure 2A). By

152 adhering to MIReAAD standards, omissions and ambiguity can be avoided even if the data are

153 shared in different formats (Figure 2B and C). Finally, we identify common problems likely to

154 be encountered across all the MIReAAD metadata and data fields, and data quality standards that

155 can be employed to avoid confusion (Box 1).

156 


\section{Box 1. Data quality standards}

No abbreviations. Abbreviations (including in columns names) are ambiguous, with the exception of measurement units (e.g. centigrade and meters).

No external legend/key files. While repetitive, all data should be explicitly given within the data table. Separate files mapping ID numbers to GPS locations, full species names, etc., should be avoided. In addition, rich metadata is essential for good data discovery and reuse.

Unambiguous dates. Because of country-level differences in date formats, data should be reported with 4 digit years, and months provided alphabetically and not numerically $(e . g$. 4-Jun-2017 or Nov 12, 2015).

Machine-readable file formats. Data should be provided in non-proprietary machine readable formats such as comma-separated text files. PDFs and multiple spreadsheets in the same document should be avoided.I

No font styling or subsection headings. Formatting (color, bold, italics, subscripts, sheet tab names, etc.) should not be required for understanding the data. Subsection headings should not be required to understand data; every line of data should be interpretable in isolation from any other line of data.

Highest precision possible. Data should be provided at the highest temporal, spatial, numerical, and taxonomic resolution available. If location (e.g., geographical coordinate) data need to be presented at a lower resolution than available for privacy reasons, this should be made clear in the submission in Study Information (Resource Metadata; Table $1)$. 
Language. Once data are ready to be deposited/submitted, all fields and data are preferably written in English. This will allow researchers and data curators worldwide to understand and reuse the data. Use of other languages is better than not publishing data. Please avoid introducing data reuse barriers through incomplete translation. For example, non-English field names in an English-language submission.

158 Examples

159 Below we provide three examples to illustrate MIReAAD compliant data (linked to

160 Supplemental Data Files 1-4, respectively). Researchers can use these data sheets as a basis for

161 formatting their own data. In these examples, note that all data meet the data quality standards of

162 Box 1; are adequately described, have columns labeled, etc. to eliminate ambiguity (even if the

163 data appear repetitive; for example, the sex and life stage are repeated in every row). Examples 1

164 and 2 should be sufficient for most data generators. Example 3 (Data Files 3-4) demonstrates a

165 more complex data collection scenario.

166

167 1. Long-format trapping data. Each row captures count data for a single species' occurrence in a 168 given sampling event. This illustrates an example of the most common mosquito collection 
protocol.

[Sup

Datasheet

$1]$.

Also

see

Figure

$2 \mathrm{~B}$.

170

171 2. Wide format trapping data. Each row captures count data from a given sampling event. Each

172 identified taxonomic group is identified in a separate column. An 'additional sample

173 information' field, 'sub-location,' has been added to describe the various locations around the

174 village where collections were made. [Sup Datasheet 2]. This illustrates an example of adult

175 mosquito populations that have been tracked over time and in specific locations. Also see Figure

$1762 \mathrm{C}$.

177

178 3. Complex trapping data scenario. Tick surveillance performed using tick drags and flags and

179 collections of ectoparasites on trapped mice. The tick drags/flags report three life stages

180 independently (adult, larvae, and nymph) [Sup Datasheet 3] . Larvae are only identified to the

181 genus, while adults and nymphs are identified to the species. Observations of different life

182 stages and sexes are preferably documented in separate records. A Sample Name is used to help

183 link these records (but would not be necessary.) The mouse survey uses an additional sample

184 information field to record the sex of the trapped mouse from which the parasites were collected

185 [Sup Datasheet 4].

\section{Discussion}

\section{MIReAAD as the path to FAIR data principles}

188 We designed MIReAAD to achieve a balance between standards that are too onerous for data

189 generators and standards that are sufficient to ensure at least minimal reusability ${ }^{31,40}$. Like all 
190 minimum standards, MIReAAD only aims at ensuring data 'Reusability'. However, ultimately

191 this will promote the implementation of data models — the explicit definition of data field

192 names, data formats (e.g., for dates and GPS locations), and controlled vocabularies (e.g., the

193 Darwin Core $^{47}$ ). Data models enable 'Interoperability', and in turn facilitate structured databases,

194 public repositories, and development of data analysis tools ${ }^{46,48}$. Deposition in open databases

195 make data 'Findable' and 'Accessible"49-51. MIReAAD compliant data contain sufficient

196 information for established aggregators/databases such as VectorBase and SCAN (Symbiota

197 Collections of Arthropods Network ${ }^{52}$ ) to process and store the data in a standardized data model

198 [e.g., Darwin Core, a widely used universal data standard that supports opportunistic observation

199 and collection data (occurrence core) as well as presence/absence and abundance data collected

200 using strict and documented methodology (event core) ${ }^{47}$, and ultimately facilitate data transfer

201 to even more comprehensive biodiversity databases [e.g. GBIF, which contains over one billion

202 species occurrence records, from thousands of environmental, ecological, and natural resource

203 investigations, including research on Arthropoda in numerous ecological and monitoring

204 projects, allowing for study of changes and trends in populations. ${ }^{51}$ ]. Indeed, in Supplemental

205 File 5, we provide an example of the mapping of data fields from this minimum information

206 standard, to DarwinCore and GBIF. In this way, MIReAAD opens the door to FAIR data and

207 more sophisticated methods to integrate data across many scales.

208

\section{Benefits to field researchers}

210 It is essential that the benefits of a minimal data standard extend not just to data re-users, but also

211 to the researchers who collect and generate data in the first place. MIReAAD provides a

212 framework for data preparation that can help scientists achieve recognized professional merit for 10 
213 sharing data such as increased citation rates, academic recognition, opportunities for co-

214 authorship, and new collaborations [sensu Roche et al. $2014^{31}$ ]. Large, deposited data sets can

215 now themselves be standalone, citable "data papers" (e.g. $\left.{ }^{53-55}\right)$ or even depositions without any

216 traditional manuscript (but as an authored 'digital product,' with persistent identifiers, such as a

217 DOI number), if desired. Data sets are increasingly recognized as valuable research outputs that

218 count towards academic recognition and professional advancement (e.g. grants, interviews, and

219 tenure). For example, several funders (e.g. United States National Science Foundation and Swiss

220 National Science Foundation) have adopted or are in the process of adopting the Declaration on

221 Research Assessments (DORA) ${ }^{56}$, offering further opportunities for data generators to gain

222 recognition and publication credit for their work ${ }^{57}$. Also, an increasing number of funders are

223 mandating public data access, and detailed data management plans are often required even at the

224 grant proposal stage. Therefore, reporting data according to MIReAAD will provide a

225 foundational pipeline for stipulating archival formats.

227 Furthermore, many data generators are also data users. Developing analyses that rely on

228 standardized fields can facilitate the development of generalized analytical tools that can be

229 easily extended to datasets beyond those that were collected by a single individual or lab. In this

230 way, they can enable extensions of work that would otherwise not happen, such as comparisons

231 of population dynamics in different locations or assessments of interspecies interactions.

232 Adopting MIReAAD therefore can both help data generators reap the benefits of sharing data

233 they have collected and enable them to more readily leverage data collected by others.

\section{Further MIReAAD applications and extensions}


236 The creation of minimum information standards for these types of databases facilitates analyses

237 of data at the scales that cannot be attained by a single individual or lab group. Linking records

238 to additional information also extends the utility of these data to address population level

239 questions. For example, a well-populated database presents opportunities to investigate

240 interactions between populations of different species of arthropod that overlap in geography, but

241 may be of interest individually to different realms of research. As a case in point, in the

242 northeastern USA, Agrilus plannipennis, the Emerald Ash Borer (EAB), is a highly destructive

243 invasive insect, monitored closely by both state and federal agencies for management ${ }^{58}$.

244 Interestingly, EAB are creating lots of new habitat for carpenter bees, a species interaction that

245 can be tracked and anticipated using large scale arthropod data.

247 Another example of the utility of linked data is for disease vectors. Data on insecticide resistance

248 linked with time and place would be valuable for coordinating control strategies within and

249 between nations and communities. Presence/absence data on infection levels would be helpful

250 for tracking and investigating disease outbreaks, and dynamics. Standardization of these data

251 would be particularly useful for pathogens that infect multiple vectors and hosts and would

252 facilitate a "One Health" approach. Other important vector phenotypes that contribute to control

253 and transmission such as pathogen susceptibility, biting preferences, and breeding behaviours

254 could be measured over time and space.

256 We note that MIRreAAD is applicable not only to abundance measurements, but could be easily

257 extended to any other kind of routinely sampled time-series field data. For example, in addition 
258 to aphid abundance, plant pathogen (such as mosaic virus) infection and insecticide resistance

259 statuses of the aphids could be reported in MIRreAAD format.

260 Conclusion

261 We present MIReAAD, a minimum information standard for representing arthropod

262 abundance data. MIReAAD will facilitate collation and analyses of data at scales that cannot be

263 attained by a single individual or lab, to address key questions across temporal and spatial scales,

264 such as within and across-year phenology of abundance of target arthropod taxa over large

265 geographical areas. This is particularly important given the pressing need to understand and

266 predict the population dynamics of harmful (e.g., disease vectors and pests) as well as beneficial

267 (e.g., pollinators, bio-control agents) arthropods in natural and human modified landscapes. This

268 is the first step for achieving the broad benefits of FAIR data for arthropod abundance. We call

269 on data generators, authors, reviewers, editors, journals, research infrastructures (e.g. data

270 repositories) and funders to embrace MIReAAD as a standard to facilitate FAIR data use and

271 compliance for arthropod abundance data.

272

273 Table 1. The MIReAAD Study Information (Resource metadata) fields. The information in this 274 table should be included with every data submission, for example by including data in the file 275 header as demonstrated in Data Files 1-4.

276

\begin{tabular}{|c|c|l|l|}
\hline Field & Details & Recommendations & Examples \\
\hline
\end{tabular}


bioRxiv preprint doi: https://doi.org/10.1101/429142; this version posted October 17, 2018. The copyright holder for this preprint (which was not certified by peer review) is the author/funder. All rights reserved. No reuse allowed without permission.

\begin{tabular}{|c|c|c|c|}
\hline Contact details & $\begin{array}{l}\text { A name, person, authority, } \\
\text { etc. that may be contacted } \\
\text { with enquiries about the } \\
\text { data. }\end{array}$ & $\begin{array}{l}\text { Include investigator } \\
\text { ORCID(s), email } \\
\text { address, website (if } \\
\text { institutional) if } \\
\text { possible. }\end{array}$ & $\begin{array}{l}\text { Kurt Vandegrift } \\
\text { orcid.org/0000-0002-5690-3300 } \\
\text { kurtvandegrift@gmail.com } \\
\text { State University } \\
\text { Agricultural Extension } \\
\text { John Smith (jsmith@StateU.edu) } \\
\text { www.StateU.edu/AgriculturalExtension/ }\end{array}$ \\
\hline $\begin{array}{l}\text { General } \\
\text { description of } \\
\text { the } \\
\text { experiment/ } \\
\text { collection set }\end{array}$ & $\begin{array}{l}\text { A short description of the } \\
\text { study objectives, sampling } \\
\text { design, and hypotheses. } \\
\text { Used to aid in browsing } \\
\text { multiple studies. } \\
\text { A short title and long form } \\
\text { name might be helpful. }\end{array}$ & $\begin{array}{l}\text { Useful things to } \\
\text { indicate are: } \\
\text { Random sampling or } \\
\text { continuous monitoring } \\
\text { in fixed locations } \\
\text { General time frames } \\
\text { and location. } \\
\text { General description of } \\
\text { where data is from. }\end{array}$ & $\begin{array}{l}\text { "Long term, fixed trapped, municipal } \\
\text { surveillance of west Nile vector population in } \\
\text { Colorado from 2000-2010" } \\
\text { "--- } \\
\text { abennsylvania Ixodes scapularis weekly } \\
\text { Continuous (weekly) monitoring of tick } \\
\text { numbers attached to White-footed mice in } \\
\text { fixed locations in Pennsylvania, USA (12 } \\
\text { sites). 2003-present." } \\
----- \\
\text { "Long term aphid emergence monitoring } \\
\text { using continuous suction traps" }\end{array}$ \\
\hline Citations & $\begin{array}{l}\text { Reference to related } \\
\text { publications, digital if } \\
\text { possible (e.g. DOI(s) or } \\
\operatorname{PMID(s)).}\end{array}$ & & $\begin{array}{l}\text { "A web-based relational database for } \\
\text { monitoring and analyzing mosquito } \\
\text { population dynamics } \\
\text { Sucaet Y, Van Hemert J, Tucker B, } \\
\text { Bartholomay L." } \\
\text { "PMID: 18714883" } \\
\text { Horiuchi, Kaho, Kosei Hashimoto, and } \\
\text { Fumio Hayashi. "Cantharidin world in air: } \\
\text { Spatiotemporal distributions of flying } \\
\text { canthariphilous insects in the forest interior." } \\
\text { Entomological Science (2018). }\end{array}$ \\
\hline $\begin{array}{l}\text { Species } \\
\text { Identification } \\
\text { Method }\end{array}$ & $\begin{array}{l}\text { A description of method of } \\
\text { species identification. } \\
\text { Particularly important for } \\
\text { cryptic species complexes. }\end{array}$ & & $\begin{array}{l}\text { "Morphological" } \\
\text { "Genotyped, using method of Smith et al } \\
\text { 2014, PMID: } 18714883 \text { " }\end{array}$ \\
\hline $\begin{array}{l}\text { Not present vs } \\
\text { zero } \\
\text { information }\end{array}$ & $\begin{array}{l}\text { Indication of what gaps, } \\
\text { zeros, NA, etc mean. }\end{array}$ & $\begin{array}{l}\text { It is imperative, } \\
\text { especially for } \\
\text { population surveys, to } \\
\text { understand the } \\
\text { difference between a } \\
\text { species was not found } \\
\text { when the collection } \\
\text { method would be } \\
\text { expected to find the } \\
\text { given species } \\
\text { (confirmed absence) } \\
\text { or a species was not }\end{array}$ & $\begin{array}{l}\text { "Zero indicates was looked for and not } \\
\text { found. NA represents a trap failure etc" }\end{array}$ \\
\hline
\end{tabular}




\begin{tabular}{|c|c|c|c|}
\hline & & $\begin{array}{l}\text { looked for (e.g. a trap } \\
\text { failure) } \\
\text { Preferably, a zero } \\
\text { indicates was looked } \\
\text { for and not found, and } \\
\text { a NA represents was } \\
\text { not looked for/trap } \\
\text { failure/ etc. } \\
\text { Blank values are } \\
\text { discouraged }\end{array}$ & \\
\hline $\begin{array}{l}\text { GPS } \\
\text { obfuscation } \\
\text { information }\end{array}$ & $\begin{array}{l}\text { If GPS data obfuscation } \\
\text { (e.g. GPS points are } \\
\text { intentionally offset from their } \\
\text { actual locations) or de- } \\
\text { resolution occurs (e.g. GPS } \\
\text { precision is intentionally } \\
\text { reduced), a statement on } \\
\text { the manner by which this } \\
\text { occurred. }\end{array}$ & $\begin{array}{l}\text { The highest resolution } \\
\text { data (e.g. trap-level, } \\
\text { specific GPS location) } \\
\text { are the most useful. It } \\
\text { is hoped that no data } \\
\text { obfuscation / de- } \\
\text { resolution occurs }\end{array}$ & $\begin{array}{l}\text { "GPS locations have been truncated to } 3 \\
\text { decimals" } \\
\text { "GPS locations obfuscated using N- } \\
\text { Dispersion" } \\
\text { "No GPS deresolution was performed" }\end{array}$ \\
\hline $\begin{array}{l}\text { Data usage } \\
\text { information }\end{array}$ & $\begin{array}{l}\text { The data reuse policy for } \\
\text { your data. } \\
\text { Please provide a creative } \\
\text { commons license } \\
\text { identification. } \\
\text { See } \\
\text { https://creativecommons.org } \\
\text { for more information. }\end{array}$ & $\begin{array}{l}\text { For data to be } \\
\text { F.A.I.R., it must be } \\
\text { Reusable. We } \\
\text { therefore recommend } \\
\text { data be provided as } \\
\text { "CC0" or "CC BY 4.0". } \\
\text { "CC0", under which } \\
\text { data are made } \\
\text { available for any use } \\
\text { without restriction or } \\
\text { particular } \\
\text { requirements on the } \\
\text { part of users } \\
\text { "CC BY } 4.0 \text { ", under } \\
\text { which data are made } \\
\text { available for any use } \\
\text { provided that } \\
\text { attribution is } \\
\text { appropriately given for } \\
\text { the sources of data } \\
\text { used, in the manner } \\
\text { specified by the owner } \\
\text { (e.g. citation). }\end{array}$ & $\begin{array}{l}\text { "CCO" } \\
\text { or } \\
\text { "CC BY 4.0" }\end{array}$ \\
\hline
\end{tabular}


bioRxiv preprint doi: https://doi.org/10.1101/429142; this version posted October 17,2018 . The copyright holder for this preprint (which was not certified by peer review) is the author/funder. All rights reserved. No reuse allowed without permission.

\begin{tabular}{|c|c|c|c|}
\hline Field(s) & Details & Recommendations & Examples \\
\hline $\begin{array}{l}\text { Start Time (for } \\
\text { collection) }\end{array}$ & $\begin{array}{l}\text { Start time of the } \\
\text { data sample } \\
\text { collection. } \\
\text { e.g. The trap was } \\
\text { set... }\end{array}$ & $\begin{array}{l}\text { Be as specific as practically } \\
\text { possible. } \\
\text { Any unambiguous format is } \\
\text { acceptable. However, do not } \\
\text { use two-digit year abbreviations. } \\
\text { If relevant, provide timezone in } \\
\text { field or in header, a } 24 \text { hour } \\
\text { clock is preferred, but should be } \\
\text { made unambiguous as to which } \\
\text { time format is being used. }\end{array}$ & $\begin{array}{l}\text { “2012-04-27" } \\
\text { “July 26, 2017" } \\
\text { "2017-Jul-26" } \\
\text { "2017-July-26 Morning " } \\
\text { "2017-Jul-26 20:00 GMT " }\end{array}$ \\
\hline $\begin{array}{l}\text { End Time (for } \\
\text { collection) }\end{array}$ & $\begin{array}{l}\text { End time of the } \\
\text { data sample } \\
\text { collection. } \\
\text { e.g. The trap was } \\
\text { collected... }\end{array}$ & $\begin{array}{l}\text { See above. } \\
\text { If instantaneous data collection } \\
\text { (e.g. a tick drag), End Time may } \\
\text { be the same as Start Time. }\end{array}$ & See above. \\
\hline Location & $\begin{array}{l}\text { The geographical } \\
\text { location of sample } \\
\text { collection. }\end{array}$ & $\begin{array}{l}\text { As detailed as possible. Latitude } \\
\text { and longitude if possible with } \\
\text { specified accuracy } \\
\text { Providing both a GPS point } \\
\text { (decimalized GPS points are } \\
\text { prefered) field and a } \\
\text { geographical name field is } \\
\text { prefered. } \\
\text { Note only providing location } \\
\text { names is highly discouraged as } \\
\text { they change over time and can } \\
\text { be ambiguous. } \\
\text { Place / Trap names and GPS } \\
\text { fields can be provided. } \\
\text { If obfuscation was used, it } \\
\text { should be indicated in the } \\
\text { Metadata (Table 1). } \\
\text { Splitting latitude and longitude } \\
\text { further into two columns further } \\
\text { reduces ambiguity. }\end{array}$ & $\begin{array}{l}\text { "Kukar Maikiya, Jigawa State, Nigeria" } \\
\text { " } 40.697 \text { " and "- } 74.015 "\end{array}$ \\
\hline
\end{tabular}




\begin{tabular}{|c|c|c|c|}
\hline $\begin{array}{l}\text { Collection } \\
\text { method }\end{array}$ & $\begin{array}{l}\text { Sampling } \\
\text { apparatus (e.g. } \\
\text { trap type, } \\
\text { observation } \\
\text { method) }\end{array}$ & & $\begin{array}{l}\text { "CDC light trap" } \\
\text { "Tick drag" } \\
\text { "Quadrat count" } \\
\text { "BG Sentinel Trap" } \\
\text { "Pitfall trap" } \\
\text { "Larval dip" } \\
\text { "Johnson suction trap" } \\
\text { "Lindgren Funnel Trap" }\end{array}$ \\
\hline $\begin{array}{l}\text { Collection } \\
\text { attractants }\end{array}$ & $\begin{array}{l}\text { The attractant/ } \\
\text { lures used to attract } \\
\text { insects to a trap or } \\
\text { collection }\end{array}$ & & $\begin{array}{l}\text { "None" } \\
\text { "Carbon dioxide" } \\
\text { "UV light" } \\
\text { "BG-Sweetscent Mosquito Lure" } \\
\text { "Human/animal bait" }\end{array}$ \\
\hline Collection area & $\begin{array}{l}\text { The spatial extent } \\
\text { (area or volume) of } \\
\text { the sample. }\end{array}$ & $\begin{array}{l}\text { If relevant (e.g., when collection } \\
\text { method is transect or quadrat), } \\
\text { in units of area or volume, the } \\
\text { spatial coverage of the sampling } \\
\text { unit } \\
\text { Note this field would not } \\
\text { typically be used for mosquito } \\
\text { collections. }\end{array}$ & $\begin{array}{l}\text { "100 m^2" } \\
\text { "1 liter" } \\
\text { "1 ha" } \\
\text { "10m^3" }\end{array}$ \\
\hline Taxonomy & $\begin{array}{l}\text { Classification of } \\
\text { sample collected. }\end{array}$ & $\begin{array}{l}\text { Scientific genus and species } \\
\text { preferred. } \\
\text { Avoid abbreviation. }\end{array}$ & $\begin{array}{l}\text { "Ixodes scapularis" } \\
\text { "Aedes aegypti" } \\
\text { 'Anopheles gambiae sensu stricto" }\end{array}$ \\
\hline
\end{tabular}


bioRxiv preprint doi: https://doi.org/10.1101/429142; this version posted October 17, 2018. The copyright holder for this preprint (which was not certified by peer review) is the author/funder. All rights reserved. No reuse allowed without permission.

\begin{tabular}{|c|c|c|c|}
\hline $\begin{array}{l}\text { Unit(s) of } \\
\text { measurement } \\
\text { and observation }\end{array}$ & $\begin{array}{l}\text { Description of } \\
\text { exactly what was } \\
\text { observed, the unit } \\
\text { for "Value" below. } \\
\text { For counts, should } \\
\text { indicate life stage, } \\
\text { sex, etc. } \\
\text { Unit measures can } \\
\text { be encoded into } \\
\text { value field header. } \\
\text { Consider multiple } \\
\text { unit fields (e.g. } \\
\text { separate fields for } \\
\text { sex and stage.) } \\
\text { See Figure } 2 \text {. }\end{array}$ & $\begin{array}{l}\text { Do not abbreviate. } \\
\text { Coded data key should be } \\
\text { provided in field name (e.g. " } 1= \\
\text { species present } 0=\text { species } \\
\text { absent") }\end{array}$ & $\begin{array}{l}\text { "Number of individuals per m^2" } \\
\text { "Female" and "Adult" } \\
\text { "Male and Female" and "Nymphs" }\end{array}$ \\
\hline Value & $\begin{array}{l}\text { The numerical } \\
\text { amount or result } \\
\text { from the sample } \\
\text { collection. } \\
\text { Often this will be a } \\
\text { quantity of } \\
\text { observed } \\
\text { individuals. } \\
\text { Unit measures can } \\
\text { be encoded into } \\
\text { value field header. } \\
\text { See Figure } 2 \text {. }\end{array}$ & $\begin{array}{l}\text { Units should be provided in a } \\
\text { separate field. }\end{array}$ & $\begin{array}{l}\text { "0" } \\
\text { "23" } \\
\text { "Yes" } \\
\text { "Not present" }\end{array}$ \\
\hline $\begin{array}{l}\text { Additional sample } \\
\text { information }\end{array}$ & $\begin{array}{l}\text { This could be more } \\
\text { than one field and } \\
\text { should be used } \\
\text { when more } \\
\text { information is } \\
\text { required to } \\
\text { understand the } \\
\text { experiment, for } \\
\text { example } \\
\text { experimental } \\
\text { variables, sub- } \\
\text { locations, etc. } \\
\text { Some users may } \\
\text { report wind speeds, } \\
\text { temperatures, } \\
\text { elevations etc. }\end{array}$ & Do not abbreviate. & $\begin{array}{l}\text { "Forest" } \\
\text { vs } \\
\text { "Field" } \\
\text { "Winter" } \\
\text { vs } \\
\text { "Summer" } \\
\text { "Inside" } \\
\text { vs } \\
\text { "Outside" } \\
\text { "200 meters above sea level" }\end{array}$ \\
\hline
\end{tabular}




\begin{tabular}{|c|c|c|c|}
\hline Sample Name & $\begin{array}{l}\text { A human readable } \\
\text { sample name. } \\
\text { May exist solely for } \\
\text { the benefit of the } \\
\text { depositor in } \\
\text { organizing their } \\
\text { data, use their own } \\
\text { internal naming } \\
\text { conventions etc. } \\
\text { May also be used } \\
\text { to tie related } \\
\text { observations } \\
\text { together. }\end{array}$ & $\begin{array}{l}\text { Naming convention is not } \\
\text { restricted, but any encoded } \\
\text { metadata should be revealed in } \\
\text { the other datafields. For } \\
\text { example, you may name a } \\
\text { sample named } \\
\text { 'Aphid1_StickyTrap_Jan4,' but } \\
\text { you will still have "Sticky Trap" } \\
\text { listed in a Collection Method } \\
\text { field, and "Jan 4, 2017" in the } \\
\text { date field. }\end{array}$ & $\begin{array}{l}\text { "Trap1_Night1" } \\
\text { "KissingBug_2" } \\
\text { “00004" } \\
\text { "Jan08_animal_4," }\end{array}$ \\
\hline
\end{tabular}

Field names in bold should be considered also required. Remaining fields are optional or depend on the complexity of the experimental design

\section{Author contributions}

The project was conceptualized by Lauren Cator and Samraat Pawar. The original draft was prepared by Michael A. Johansson, Samuel S.C. Rund, Naveed Heydari, Kurt Vandegrift, Matthew Watts, and Samraat Pawar. Visualization was prepared by Kurt Vandegrift, Samuel S.C. Rund, Samraat Pawar, and Michael A. Johansson. Review \& Editing was performed by all 289 the authors.

\section{Competing interest statement}

292 The authors declare no competing interests.

\section{3}

\section{Acknowledgements}

The seeds of this effort were planted in 2016 at a meeting of VectorBiTE, which is a crossdisciplinary research coordination network $(\mathrm{RCN})$ for disease vectors. Samuel S.C. Rund, Matthew Watts, Kurt Vandegrift, Naveed Heydari, Cynthia Lord, Michael Johansson, Samraat Pawar, and Sadie J. Ryan, received travel funding from NIH grant 1R01AI122284-01 and BBSRC grant BB/N013573/1 as part of the joint [NIH-NSF-USDA-BBSRC] Ecology and Evolution of Infectious Diseases program. 
302 Samuel S.C. Rund was funded by the Royal Society (NF140517). Rund, Daniel Lawson, Robert

303 M. MacCallum, Sarah A. Kelly, Gloria I. Giraldo-Calderon and Scott J. Emrich were supported

304 by the National Institute of Allergy and Infectious Diseases, National Institutes of Health,

305 Department of Health and Human Services, under Contract No. HHSN272201400029C

306 (VectorBase Bioinformatics Resource Center).

307

308 Kurt Vandegrift was funded by the National Science Foundation Ecology and Evolution of

309 Infectious Diseases program (1619072).

311 Naveed Heydari and Sadie J. Ryan were funded by National Science Foundation (NSF DEB

312 EEID 1518681).

314 Sadie J. Ryan was additionally funded by NIH 1R01AI136035-01, and CDC grant

315 1U01CK000510-01: Southeastern Regional Center of Excellence in Vector-Borne

316 Diseases: the Gateway Program. This publication was supported by the Cooperative Agreement

317 Number above from the Centers for Disease Control and Prevention. Its contents are solely the

318 responsibility of the authors and do not necessarily represent the official views of the Centers for

319 Disease Control and Prevention.

321 Jennifer M. Zaspel was funded by the National Science Foundation Division of Biological 322 Infrastructure (NSF 1561448, NSF 1601957). 


\section{Figures}

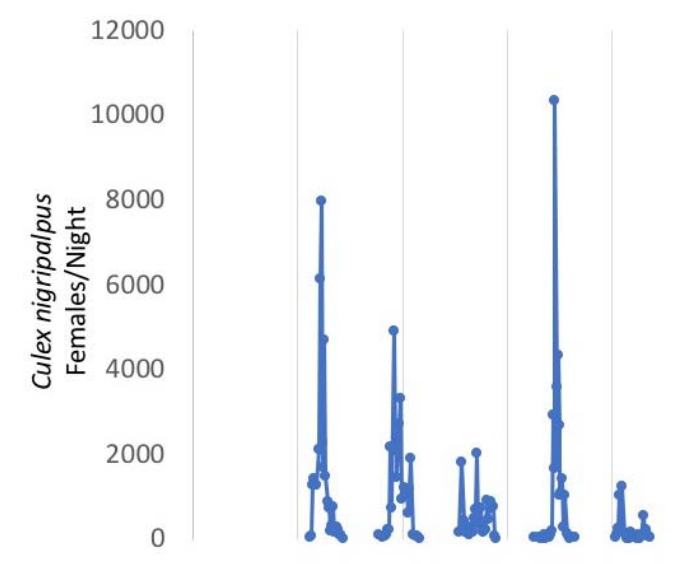

20122013

2014

20152016

Figure 1. Example population abundance time-series. 
A.

\begin{tabular}{|c|c|c|c|c|c|}
\hline \multirow{3}{*}{$\begin{array}{l}\text { Is this date of collection? } \\
\text { How long was trap set? }\end{array}$} & \multirow[b]{2}{*}{ Date } & \multicolumn{3}{|c|}{$\begin{array}{l}\text { What is being counted? } \\
\text { Adults? Females? }\end{array}$} & \\
\hline & & Trap & Count & Species & \multirow{3}{*}{$\begin{array}{l}\text { Ambiguous genus: } \\
\text { Culex inornata or } \\
\text { Culiseta inornata? }\end{array}$} \\
\hline & $12 / 11 / 18$ & LT-5 & 6 & C. inornata & \\
\hline & $12 / 11 / 18$ & LT-6 & 4 & C. inornata & \\
\hline & $12 / 11 / 18$ & LT-7 & 6 & C. inornata & \\
\hline \multirow{3}{*}{$\begin{array}{l}\text { Ambiguous date format: } \\
\text { Different countries use alternate day, } \\
\text { month, and year orders }\end{array}$} & $12 / 11 / 18$ & LT-5 & 8 & A. francisc. & \multirow{3}{*}{$\begin{array}{l}\text { Ambiguous species: } \\
\text { Anopheles franciscanus or } \\
\text { Anopheles Franciscoi? }\end{array}$} \\
\hline & $12 / 11 / 18$ & LT-6 & 3 & A. francisc. & \\
\hline & $12 / 11 / 18$ & LT-7 & 11 & A. francisc. & \\
\hline
\end{tabular}

A. Where is this trap located? What kind of trap?
"LT" could be "light trap," but there are multiple kinds.
Was an attractant used?

B.

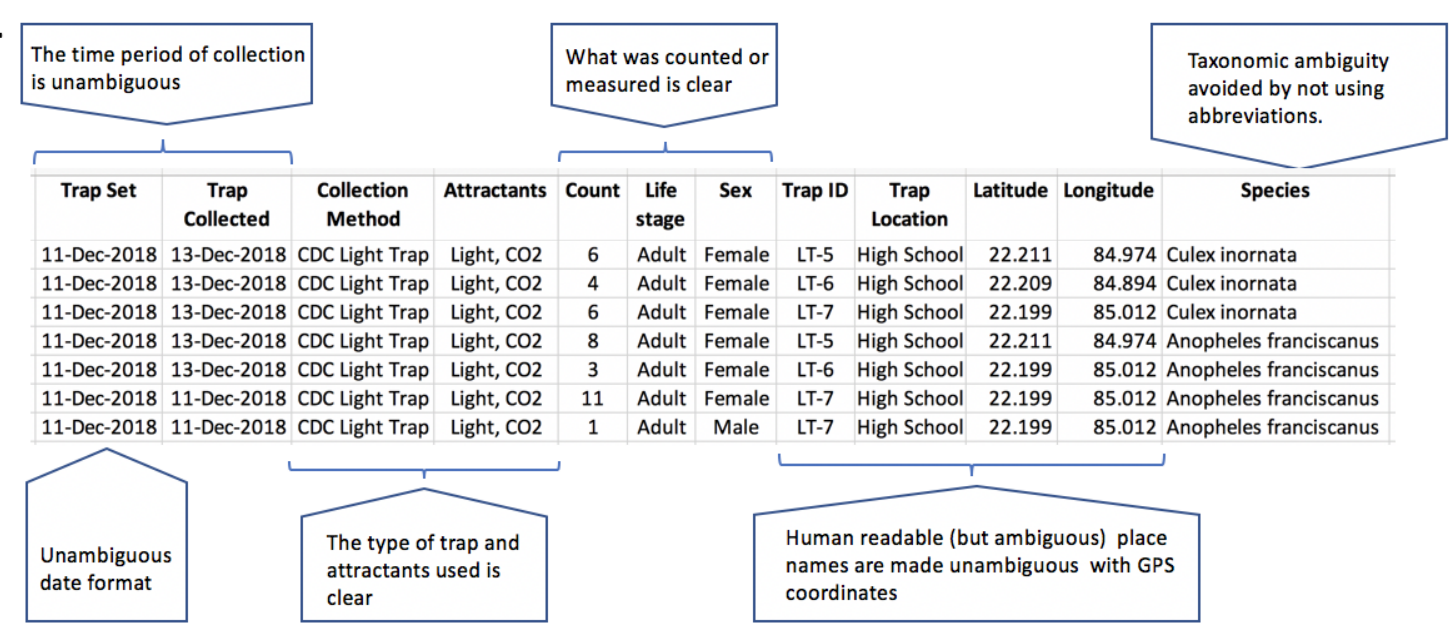

C.

Figure 2. MIReAAD reduces data ambiguity. A. Seemingly clean data can still lack key information or have ambiguous metadata, hindering data reuse. B. MIReAAD compliant data includes the metadata necessary for data reuse and removes ambiguity. C. Note data can be formatted differently, but still be MIReAAD complaint, such as by presenting data in a wide format

334 1. Seastedt, T. R. \& Crossley, D. A. The Influence of Arthropods on Ecosystems. Bioscience 335 34, 157-161 (1984).

336 2. Arthropod Regulation of Micro- and Mesobiota in Below-Ground Detrital Food Webs | 
Annual Review of Entomology.

3. Whiles, M. R. \& Charlton, R. E. The ecological significance of tallgrass prairie arthropods. Annu. Rev. Entomol. 51, 387-412 (2006).

4. Losey, J. E. \& Vaughan, M. The Economic Value of Ecological Services Provided by Insects. Bioscience 56, 311-323 (2006).

5. Bradshaw, C. J. A. et al. Massive yet grossly underestimated global costs of invasive insects. Nat. Commun. 7, 12986 (2016).

6. Bebber, D. P., Ramotowski, M. A. T. \& Gurr, S. J. Crop pests and pathogens move polewards in a warming world. Nat. Clim. Chang. 3, 985 (2013).

7. Sparling, P. F., Hamburg, M. A., Relman, D. A., Choffnes, E. R. \& Mack, A. Vector-Borne Diseases : Understanding the Environmental, Human Health, and Ecological Connections, Workshop Summary. Forum on Microbial Threats: Board on Global Health. (National Academies Press, 2008).

8. Minjauw, B. \& McLeod, A. Tick-borne diseases and poverty : the impact of ticks and tickborne diseases on the livelihoods of small-scale and marginal livestock owners in India and eastern and southern Africa. (Centre for Tropical Veterinary Medicine, 2003).

9. Van den Bossche, P., de La Rocque, S., Hendrickx, G. \& Bouyer, J. A changing environment and the epidemiology of tsetse-transmitted livestock trypanosomiasis. Trends Parasitol. 26, 236-243 (2010).

10. WHO | Vector-borne diseases. (2017).

11. Gubler, D. J. Resurgent vector-borne diseases as a global health problem. Emerg. Infect. Dis. 4, 442-450 (1998).

12. Elbers, A. R. W., Koenraadt, C. J. M. \& Meiswinkel, R. Mosquitoes and Culicoides biting midges: vector range and the influence of climate change. Rev. Sci. Tech. 34, 123-137 (2015).

13. Sakai, A. K. et al. The Population Biology of Invasive Species. Annu. Rev. Ecol. Syst. 32, 305-332 (2001).

14. Rund, S. S. C. \& Martinez, M. E. Rescuing Troves of Data to Tackle Emerging MosquitoBorne Diseases. bioRxiv 096875 (2018). doi:10.1101/096875

15. Foley, D. H., Maloney, F. A., Jr, Harrison, F. J., Wilkerson, R. C. \& Rueda, L. M. Online spatial database of US Army Public Health Command Region-West mosquito surveillance records: 1947-2009. US Army Med. Dep. J. 29-36 (2011).

16. Hutchinson, M. L., STROHECKER, Simmons, T. W., Kyle, A. D. \& Helwig, M. W. Prevalence Rates of Borrelia burgdorferi (Spirochaetales: Spirochaetaceae), Anaplasma phagocytophilum (Rickettsiales: Anaplasmataceae), and Babesia microti (Piroplasmida: Babesiidae) in Host-Seeking Ixodes scapularis (Acari: Ixodidae) from Pennsylvania. Journal of Medical Entomology 52, 693-698 (2015).

17. Magarey, R. D. et al. Risk maps for targeting exotic plant pest detection programs in the United States: US risk maps for exotic plant pest detection. EPPO Bulletin 41, 46-56 (2011).

18. Wilson, B. E., Beuzelin, J. M., VanWeelden, M. T., Reagan, T. E. \& Way, M. O. Monitoring Mexican Rice Borer (Lepidoptera: Crambidae) Populations in Sugarcane and Rice With Conventional and Electronic Pheromone Traps. J. Econ. Entomol. 110, 150-156 (2017).

19. Chandler, M. et al. Contribution of citizen science towards international biodiversity 
monitoring. Biol. Conserv. 213, 280-294 (2017).

20. Kampen, H. et al. Approaches to passive mosquito surveillance in the EU. Parasit. Vectors 8, 9 (2015).

21. Suprayitno, N., Narakusumo, R. P., von Rintelen, T., Hendrich, L. \& Balke, M. Taxonomy and Biogeography without frontiers - WhatsApp, Facebook and smartphone digital photography let citizen scientists in more remote localities step out of the dark. Biodivers Data J e19938 (2017).

22. Seltmann, K. C. et al. LepNet: The Lepidoptera of North America Network. Zootaxa 4247, 73-77 (2017).

23. Short, A. E. Z., Dikow, T. \& Moreau, C. S. Entomological Collections in the Age of Big Data. Annu. Rev. Entomol. 63, 513-530 (2018).

24. Horton, R. (Comment) Offline: What is medicine's 5 sigma? The Lancet 235, 1380 (2015).

25. Nakagawa, S. \& Parker, T. H. Replicating research in ecology and evolution: feasibility, incentives, and the cost-benefit conundrum. BMC Biol. 13, 88 (2015).

26. Nosek, B. A. et al. Promoting an open research culture. Science 348, 1422-1425 (2015).

27. Parker, T. H. et al. Transparency in Ecology and Evolution: Real Problems, Real Solutions. Trends Ecol. Evol. 31, 711-719 (2016).

28. Smaldino, P. E. \& McElreath, R. The natural selection of bad science. R Soc Open Sci 3, 160384 (2016).

29. Ihle, M., Winney, I. S., Krystalli, A. \& Croucher, M. Striving for transparent and credible research: practical guidelines for behavioral ecologists. Behav. Ecol. 28, 348-354 (2017).

30. Poisot, T. E., Mounce, R., Gravel - Ideas in Ecology and, D. \& 2013. Moving toward a sustainable ecological science: don't let data go to waste! queens.scholarsportal.info (2013).

31. Roche, D. G. et al. Troubleshooting public data archiving: suggestions to increase participation. PLoS Biol. 12, e1001779 (2014).

32. Culley, T. M. The frontier of data discoverability: Why we need to share our data. Applications in Plant Sciences 5, (2017).

33. Gerstner, K. et al. Will your paper be used in a meta $\square$ analysis? Make the reach of your research broader and longer lasting. Wiley Online Library (2017).

34. Ioannidis, J. P. A. et al. Repeatability of published microarray gene expression analyses. Nat. Genet. 41, 149-155 (2009).

35. Gilbert, K. J. et al. Recommendations for utilizing and reporting population genetic analyses: the reproducibility of genetic clustering using the program STRUCTURE. Mol. Ecol. 21, 4925-4930 (2012).

36. Roche, D. G., Kruuk, L. E. B., Lanfear, R. \& Binning, S. A. Public Data Archiving in Ecology and Evolution: How Well Are We Doing? PLoS Biol. 13, e1002295 (2015).

37. Renaut, S., Budden, A. E., Gravel, D., Poisot, T. \& Peres-Neto, P. Management, Archiving, and Sharing for Biologists and the Role of Research Institutions in the Technology-Oriented Age. Bioscience 68, 400-411 (2018).

38. Wilkinson, M. D. et al. The FAIR Guiding Principles for scientific data management and stewardship. Sci Data 3, 160018 (2016).

39. Wilkinson, M. D. et al. A design framework and exemplar metrics for FAIRness. Sci Data 5, 180118 (2018).

40. Taylor, C. F. et al. The minimum information about a proteomics experiment (MIAPE). 
Nat. Biotechnol. 25, 887-893 (2007).

41. Yilmaz, P. et al. Minimum information about a marker gene sequence (MIMARKS) and minimum information about any (x) sequence (MIxS) specifications. Nat. Biotechnol. 29, 415-420 (2011).

42. Lourenço, A. et al. Minimum information about a biofilm experiment (MIABiE): standards for reporting experiments and data on sessile microbial communities living at interfaces. Pathog. Dis. 70, 250-256 (2014).

43. Brazma, A., Hingamp, P., Quackenbush, J., Sherlock - Nature ..., G. \& 2001. Minimum information about a microarray experiment (MIAME) — toward standards for microarray data. nature.com (2001).

44. Bustin, S. A. et al. The MIQE guidelines: minimum information for publication of quantitative real-time PCR experiments. Clin. Chem. 55, 611-622 (2009).

45. York, W. S. et al. MIRAGE: the minimum information required for a glycomics experiment. Glycobiology 24, 402-406 (2014).

46. Taylor, C. F. et al. Promoting coherent minimum reporting guidelines for biological and biomedical investigations: the MIBBI project. Nat. Biotechnol. 26, 889-896 (2008).

47. Wieczorek, J. et al. Darwin Core: an evolving community-developed biodiversity data standard. PLoS One 7, e29715 (2012).

48. Giraldo-Calderón, G. I. et al. VectorBase: an updated bioinformatics resource for invertebrate vectors and other organisms related with human diseases. Nucleic Acids Res. 43, D707-13 (2015).

49. Benson, D. A. et al. GenBank. Nucleic Acids Res. 41, D36-42 (2013).

50. Berman, H., Henrick, K. \& Nakamura, H. Announcing the worldwide Protein Data Bank. Nat. Struct. Biol. 10, 980 (2003).

51. GBIF. Available at: http://gbif.org. (Accessed: 26th March 2018)

52. Heinrich, P. L., Gilbert, E., Cobb, N. S. \& Franz, N. Symbiota collections of arthropods network (SCAN): A data portal built to visualize, manipulate, and export species occurrences.

53. Perryman, S. A. M. et al. The electronic Rothamsted Archive (e-RA), an online resource for data from the Rothamsted long-term experiments. Sci Data 5, 180072 (2018).

54. Gossner, M. M. et al. A summary of eight traits of Coleoptera, Hemiptera, Orthoptera and Araneae, occurring in grasslands in Germany. Sci Data 2, 150013 (2015).

55. Hedefalk, F., Svensson, P. \& Harrie, L. Spatiotemporal historical datasets at micro-level for geocoded individuals in five Swedish parishes, 1813-1914. Sci Data 4, 170046 (2017).

56. The American Society for Cell Biology. San Francisco Declaration on Research Assessment. (2012). Available at: http://www.ascb.org/wpcontent/uploads/2017/07/sfdora.pdf.

57. Chavan, V. \& Penev, L. The data paper: a mechanism to incentivize data publishing in biodiversity science. BMC Bioinformatics 12 Suppl 15, S2 (2011).

58. Abell, K. J., Bauer, L. S., Duan, J. J. \& Van Driesche, R. Long-term monitoring of the introduced emerald ash borer (Coleoptera: Buprestidae) egg parasitoid, Oobius agrili (Hymenoptera: Encyrtidae), in Michigan, USA and evaluation of a newly developed monitoring technique. Biol. Control 79, 36-42 (2014). 